\title{
Neuroanesthesia and Intensive Care
}

\section{Preconditioning with prolonged oxygen exposure induces ischemic tolerance in the brain via oxygen free radical formation}

\author{
[Le préconditionnement relevant d'une exposition prolongée à l'oxygène induit une \\ tolérance ischémique dans le cerveau par la formation de radicaux libres d'oxygène]
}

Xijing Zhang MD, ${ }^{*}$ Lize Xiong MD, ${ }^{*}$ Wenneng Hu MD, ${ }^{*}$ Yu Zheng MD, ${ }^{*}$ Zhenghua Zhu MD, ${ }^{*}$

Yanhong Liu MD, ${ }^{*}$ Shaoyang Chen $\mathrm{MD},{ }^{*} \mathrm{Xi}$ Wang $\mathrm{MD} \dagger$

Purpose: To determine if $100 \%$ oxygen $\left(\mathrm{O}_{2}\right)$ inhalation induces ischemic tolerance to focal cerebral ischemia and if the effect is induced via $\mathrm{O}_{2}$ free radical formation.

Methods: Experiment 1: 36 rats were randomly assigned to four groups ( $n=9$ each): Group A, control rats inhaled air for $24 \mathrm{hr}$; Groups B, C and D animals inhaled 100\% $\mathrm{O}_{2}$ for six hours, $12 \mathrm{hr}$ and $24 \mathrm{hr}$ respectively. Experiment 2: 32 rats were randomly assigned to four groups ( $n=8$ each): Groups $E$ and $F$ rats received normal saline $\left(5 \mathrm{~mL} \cdot \mathrm{kg}^{-1}\right.$ intraperitoneally) and then inhaled air (Group E) or 100\% O (Group F) for 24 hr; Groups G and H animals received $10 \%$ dimethylthiourea $\left(500 \mathrm{mg} \cdot \mathrm{kg}^{-1}\right.$ intraperitoneally) and then inhaled $100 \% \mathrm{O}_{2}$ (Group G) or air (Group H) for 24 hr. Twenty-four hours after the treatments, the right middle cerebral artery was occluded in all rats for $120 \mathrm{~min}$. The neurologic deficit scores (NDS) and brain infarct volumes were evaluated at 24 $\mathrm{hr}$ after reperfusion.

Results: Experiment I: the infarct volume and NDS of Group D were smaller than in controls ( $P=0.004$ and 0.042 respectively). The infarct volume was reduced by $47 \%$ in Group D. There was no statistical difference among Groups A, B and C. Experiment 2: the infarct volume and NDS in Group F were less than in controls (Group E; $P=0.00$ I and 0.036 respectively). The infarct volume was reduced by $60 \%$ in Group F. There was no difference among Groups E, G and H.

Conclusion: Our study demonstrates that preconditioning with $100 \% \mathrm{O}_{2}$ for $24 \mathrm{hr}$ can induce ischemic tolerance via formation of $\mathrm{O}_{2}$ free radicals in transient focal cerebral ischemia in rats.
Objectif : Déterminer si l'inhalation d'oxygène à $100 \%\left(\mathrm{O}_{2}\right)$ induit une tolérance ischémique à une ischémie cérébrale focale et si l'effet est causé par la formation de radicaux libres d' $\mathrm{O}_{2}$.

Méthode : Essai 1: 36 rats ont été répartis au hasard en quatre groupes ( $n=9$ chacun): Groupe A, les rats témoins ont inhalé de l'air pendant $24 \mathrm{~h}$; Groupes $B, C$ et $D$, les animaux ont inhalé de l' $\mathrm{O}_{2}$ à $100 \%$ pendant six heures, $12 \mathrm{~h}$ et $24 \mathrm{~h}$, respectivement. Essai $2: 32$ rats répartis au hasard en quatre groupes ( $n=8$ chacun): Groupes $E$ et $F$, les rats ont reçu une solution saline (une dose intrapéritonéale de $5 \mathrm{~mL} \cdot \mathrm{kg}^{-1}$ ) et ont ensuite inhalé de l'air (Groupe E) ou de l'O $\mathrm{O}_{2}$ à $100 \%$ (Groupe F) pendant $24 \mathrm{~h}$; Groupes $\mathrm{G}$ et H, les animaux ont reçu du diméthylthiourée à $10 \%$ (dose intrapéritonéale de 500 $\mathrm{mg} \cdot \mathrm{kg}^{-1}$ ) et ont ensuite inhalé de l'O $\mathrm{O}_{2}$ à $100 \%$ (Groupe G) ou de l'air (Groupe $H$ ) pendant $24 \mathrm{~h}$. Vingt-quatre heures après le traitement, nous avons procédé à l'occlusion de l'artère cérébrale moyenne droite chez tous les rats pendant $120 \mathrm{~min}$. Les scores de déficit neurologique (SDN) et les volumes de l'infarctus cérébral ont été évalués 24 h après la reperfusion.

Résultats : Essai I : le volume de l'infarctus et le SDN du Groupe D ont été plus faibles que ceux du Groupe témoin ( $P=0,004$ et 0,042 respectivement). Le volume de l'infarctus a été réduit de $47 \%$ dans le Groupe D. II n'y avait pas de différence statistique entre les Groupes A, B et C. Essai 2 : le volume de l'infarctus et le SDN du Groupe F ont été plus faibles que ceux du Groupe témoin (Groupe $E$; $P=0,00$ I et 0,036 respectivement). Le volume de l'infarctus a été réduit de 60 $\%$ dans le Groupe F. Les Groupes E, G et H étaient comparables.

Conclusion : Le préconditionnement avec de l' $\mathrm{O}_{2}$ à $100 \%$ pendant $24 \mathrm{~h}$ peut induire une tolérance ischémique par la formation de radicaux libres d'O $\mathrm{O}_{2}$ pendant une ischémie cérébrale focale chez les rats.

From the Department of Anesthesiology, ${ }^{*}$ Xijing Hospital; and the Institute of Neuroscience, $†$ the Fourth Military Medical University, Xi'an, Shaanxi, China.

Address correspondence to: Dr. Lize Xiong, Department of Anesthesiology, Xijing Hospital, Xi'an, Shaanxi, 710032, China. Phone: +86

29-83375337; Fax: +86-29-82510219; E-mail: lxiong@fmmu.edu.cn

This work was supported in part by the National Natural Science Foundation of China (Grant 30170907 to Dr. Xiong).

Accepted for publication February 27, 2003.

Revision accepted December 1, 2003. 
I SCHEMIC tolerance (IT) is an endogenous protective mechanism in which a sublethal stimulus induces tolerance to a subsequent lethal ischemic injury. This powerful phenomenon holds substantial promise for identifying novel neuroprotective agents that can be used to treat various neurological disorders, such as neurodegenerative diseases and stroke. ${ }^{l}$ Since the first description of ischemic preconditioning, it has been demonstrated experimentally that endotoxin, tumour necrosis factor- $\alpha$, metabolic inhibitors and 3-nitro-propionic acid are able to mimic ischemic preconditioning and induce IT in the brain. ${ }^{2-8}$ Unfortunately, the clinical use of these substances is hardly acceptable because of their toxicity or side effects. Hyperbaric oxygen $\left(\mathrm{O}_{2}\right)$ is also able to mimic ischemic preconditioning and induce neuroprotection against ischemic injury in the animal brain and spinal cord. ${ }^{9-13}$ It is hyperoxia, not hyperbaricity, that plays the critical role in the induction of tolerance against ischemic injury in the animal brain $^{11}$ and spinal cord. ${ }^{12}$ Therefore, we hypothesized that the prolonged inhalation of a high concentration of $\mathrm{O}_{2}$ would result in a similar effect to preconditioning with hyperbaric $\mathrm{O}_{2}$.

It was suggested that hyperbaric $\mathrm{O}_{2}$ promoted IT by generation of $\mathrm{O}_{2}$ free radicals (OFR). ${ }^{11}$ OFR are considered to present a common signal in IT induction. ${ }^{14,15}$ Hydroxyl radicals $(\cdot \mathrm{OH})$ may play an important role in IT induction. ${ }^{16}$ OFR might also be involved in brain IT induction by pretreatment with prolonged inhalation of pure $\mathrm{O}_{2}$. Therefore, dimethylthiourea (DMTU), a highly effective $\mathrm{OH}$ scavenger, was used to block the brain IT induction.

The present study was conducted to determine if preconditioning with pure $\mathrm{O}_{2}$ inhalation could induce IT in a focal cerebral ischemic rat model and, if so, what was the role of OFR in the IT induction.

\section{Methods}

\section{Animals and group assignment}

The experimental protocol was approved by the Ethics Committee for Animal Experimentation and carried out according to the Guidelines for Animal Experimentation of the Fourth Military Medical University. The animals were provided by the Experimental Animal Centre of our institute.

This study consisted of two experiments. Experiment 1: 36 male Sprague-Dawley rats weighing 280 to $330 \mathrm{~g}$ were randomly assigned to one of four groups $(n=9$ each) using the following randomization procedure. First, the rats were numbered from 1 to 36 . Second, 36 random numbers were generated by a computer and each random number assigned to a rat. The numbers were then arranged in numerical sequence. Rats in Groups A, B, C and D were 1 to 9,10 to 18,19 to 27 and 28 to 36 respectively. Animals in Group A (control) inhaled room air for $24 \mathrm{hr}$; animals in Groups B, C and $\mathrm{D}$ inhaled $100 \% \mathrm{O}_{2}$ for six hours, $12 \mathrm{hr}$ and $24 \mathrm{hr}$ respectively. Experiment 2: 32 male Sprague-Dawley rats were randomly assigned (see above) to one of four groups $(n=8$ each): animals in Groups $\mathrm{E}$ (control) and $\mathrm{F}$ received ip normal saline $\left(5 \mathrm{~mL} \cdot \mathrm{kg}^{-1}\right)$ just before inhaling room air (Group E) or $100 \% \mathrm{O}_{2}$ (Group F) for $24 \mathrm{hr}$; animals in Groups $\mathrm{G}$ and $\mathrm{H}$ received ip 10\% DMTU (500 mg. $\mathrm{kg}^{-1}$, Fluka Ltd., Tsukuba, Japan) just before inhaling $100 \% \mathrm{O}_{2}$ (Group $\mathrm{G}$ ) or room air (Group H) for $24 \mathrm{hr}$.

\section{Pure $\mathrm{O}_{2}$ or room air inbalation}

The animals were placed into an air-tight container $(50 \mathrm{~cm} \times 30 \mathrm{~cm} \times 25 \mathrm{~cm})$ with an inlet and an outlet. Soda lime at the bottom of the container was used to absorb carbon dioxide. $\mathrm{O}_{2}\left(\mathrm{FIO}_{2}\right.$ l.0) or air at the rate of $3 \mathrm{~L} \cdot \mathrm{min}^{-1}$ was connected to the inlet during pretreatment. An $\mathrm{O}_{2}$ analyzer (Brüel \& Kjær, Naerum, Denmark) was used to monitor the $\mathrm{O}_{2}$ concentration in the container. The right femoral artery was cannulated with a PE-50 polyethylene catheter. Arterial blood was sampled through the catheter at the end of exposure to $\mathrm{O}_{2}$ or room air for determination of arterial $\mathrm{O}_{2}$ tension $\left(\mathrm{PaO}_{2}\right)$, arterial carbon dioxide tension $\left(\mathrm{PaCO}_{2}\right)$, and $\mathrm{pH}$ in an additional 12 rats in experiment 1 ( $n=3$ in each group). Arterial blood gases were measured using the OMNI Modular System (AVL List GmbH Medizintechnik, Graz, Austria).

\section{Focal cerebral ischemia}

The rats were fasted for $12 \mathrm{hr}$ but were allowed free access to water before surgery. Twenty-four hours after the exposure to $100 \% \mathrm{O}_{2}$ or room air, transient focal cerebral ischemia was induced in all rats. Anesthesia was induced with $4 \%$ isoflurane and was maintained with $2 \%$ isoflurane delivered by a mask. Focal cerebral ischemia was induced as described by Longa et al. ${ }^{17}$ Briefly, the right common carotid artery and the right external carotid artery were exposed through a ventral midline neck incision, and were ligated proximally. A blunt tip 3-0 nylon monofilament suture (Ethinon Nylon Suture, Ethicon Inc., Osaka, Japan) was inserted through the arteriotomy in the common carotid artery just below the carotid bifurcation, and positioned into the internal carotid artery to a point approximately 17 to $18 \mathrm{~mm}$ distal to the carotid bifurcation until a mild resistance was felt, thereby occluding the origins of the anterior cerebral and middle cerebral arteries. Reperfusion was accom- 
plished by withdrawing the suture after $120 \mathrm{~min}$ of ischemia. The incision sites were infiltrated with $0.25 \%$ bupivacaine hydrochloride for postoperative analgesia. Rectal temperature was monitored (Spacelabs Medical Inc., Redmond, WA, USA) and maintained at 37.0 to $37.5^{\circ} \mathrm{C}$ by surface heating and cooling during surgery.

\section{Recovery and neurobehavioural evaluation}

After the suture was withdrawn, the rats were returned to their cages with free access to food and water. Twenty-four hours after reperfusion, the animals were assessed neurologically by an investigator who was unaware of animal grouping. A six-point scale modified from that previously described by Longa et al. ${ }^{17}$ was used for neurologic assessment: $0=$ no deficit; $1=$ failure to extend left forepaw fully; 2 = circling to the left; 3 = falling to the left; $4=$ no spontaneous walking with a depressed level of consciousness; $5=$ dead.

\section{Infarct volume assessment}

Twenty-four hours after reperfusion, the rats were reanesthetized with $4 \%$ isoflurane in $\mathrm{O}_{2}$ and decapitated. The brains were rapidly removed and cooled in iced saline for ten minutes. Six 2-mm thick coronal sections were cut with the aid of a brain matrix. Sections were immersed in 2\% 2,3,5-triphenyltetrazolium chloride at $37^{\circ} \mathrm{C}$ for $30 \mathrm{~min}$ and then transferred to $10 \%$ buffered formalin solution for fixation. At $24 \mathrm{hr}$ after fixation, the brain slices were photographed with a digital camera (Kodak DC240, Eastman Kodak Co., Rochester, NY, USA) connected to a computer. Unstained areas were defined as infarct, and were measured using image analysis software (Adobe Photoshop 5.0CS, Windows, San Jose, CA, USA). The infarct volume was calculated by measuring the unstained area in each slice, multiplying it by slice thickness $(2 \mathrm{~mm})$, and then summating all six slices.

\section{Statistical analysis}

The infarct volumes and blood gases are expressed as mean \pm SD. One-factor ANOVA was used to compare the infarct volumes, $\mathrm{pH}, \mathrm{PaO}_{2}$ and $\mathrm{PaCO}_{2}$ among the experimental groups. The neurologic deficit scores (NDS) were analyzed using Kruskal-Wallis test followed by the Mann-Whitney U test. A $P<0.05$ was considered statistically significant.

\section{Results}

\section{Experiment 1}

The results of arterial blood gas analyses are presented in Table I. The $\mathrm{PaO}_{2}$ of $\mathrm{O}_{2}$-pretreated animals was much higher than that of animals breathing room air $(P<0.01)$.
TABLE I Arterial blood gases at the end of treatment

\begin{tabular}{lllll}
\hline Groups & $A$ & $B$ & $C$ & $D$ \\
\hline $\mathrm{pH}$ & $7.38 \pm 0.02$ & $7.34 \pm 0.06$ & $7.35 \pm 0.03$ & $7.32 \pm 0.05$ \\
$\mathrm{PaO}_{2}(\mathrm{mmHg})$ & $95 \pm 8$ & $389 \pm 39^{*}$ & $396 \pm 41^{*}$ & $423 \pm 32^{*}$ \\
$\mathrm{PaCO}_{2}(\mathrm{mmHg})$ & $43 \pm 11$ & $45 \pm 7$ & $42 \pm 8$ & $38 \pm 9$ \\
\hline
\end{tabular}

Mean $\pm \mathrm{SD}, n=3$ in each group. ${ }^{*} P<0.01$ compared with $\mathrm{A}$ Group. A = control rats exposed to room air for $24 \mathrm{hr} ; \mathrm{B}, \mathrm{C}$ and $\mathrm{D}=$ rats exposed to $100 \% \mathrm{O}_{2}$ for six hours, $12 \mathrm{hr}$ and $24 \mathrm{hr}$ respectively.

TABLE II Neurologic deficit scores $24 \mathrm{hr}$ after reperfusion in Groups A-D

\begin{tabular}{llllllll}
\hline \multirow{6}{*}{ Groups } & & \multicolumn{7}{c}{ Neurologic deficit scores } & \\
& 0 & 1 & 2 & 3 & 4 & 5 & \\
\hline A & 1 & 1 & 3 & 3 & 1 & $2(0-4)$ \\
B & & 2 & 4 & 3 & & $2(1-4)$ \\
C & 1 & 1 & 5 & 1 & 1 & $2(0-4)$ \\
D & 4 & 2 & 3 & & & $1(0-2)^{*}$ \\
\hline
\end{tabular}

${ }^{*} P=0.042$ compared with Group A. A = control rats exposed to room air for $24 \mathrm{hr}$ before focal cerebral ischemia; $\mathrm{B}, \mathrm{C}$ and $\mathrm{D}=$ rats exposed to $100 \% \mathrm{O}_{2}$ for six hours, $12 \mathrm{hr}$ and $24 \mathrm{hr}$ respectively before focal cerebral ischemia.

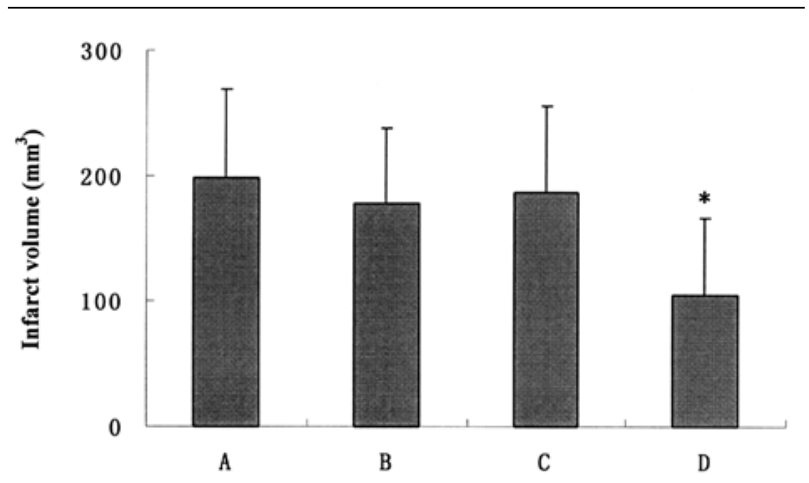

FIGURE 1 Infarct volumes at $24 \mathrm{hr}$ after reperfusion. ${ }^{*} P=$ 0.004 compared with Group A. Data are presented as mean \pm SD. $\mathrm{A}=$ control rats exposed to room air for $24 \mathrm{hr} ; \mathrm{B}, \mathrm{C}$ and $\mathrm{D}=$ exposure to $100 \% \mathrm{O}_{2}$ for six hours, $12 \mathrm{hr}$ and $24 \mathrm{hr}$ respectively before focal cerebral ischemia.

All rats survived until $24 \mathrm{hr}$ after reperfusion. NDS were lower in Group D (Table II; Group D vs control $P=0.042$ ).

The infarct volume in Group D was significantly smaller than in the control group $(47 \%$ reduction, $P=$ $0.004)$. There was no significant difference in infarct 
TABLE III Neurologic deficit scores $24 \mathrm{hr}$ after reperfusion in Groups E-H

\begin{tabular}{lcccccl}
\hline \multicolumn{7}{c}{ Neurologic deficit scores } \\
& 0 & 1 & 2 & 3 & 4 & 5 \\
\hline $\mathrm{E}$ & & 1 & 5 & 1 & 1 & $2(1-4)$ \\
$\mathrm{F}$ & 4 & 3 & 1 & & & $1(0-2)^{*}$ \\
$\mathrm{G}$ & & 1 & 4 & 3 & & $2(1-4)$ \\
$\mathrm{H}$ & & & 5 & 2 & 1 & $2(2-4)$ \\
\hline
\end{tabular}

${ }^{*} P=0.036$ compared with Group $\mathrm{E}$. $\mathrm{E}=$ control group, normal saline $\left(5 \mathrm{~mL} \cdot \mathrm{kg}^{-1}\right)$ intraperitoneally before exposure to room air for $24 \mathrm{hr} ; \mathrm{F}=$ normal saline $\left(5 \mathrm{~mL} \cdot \mathrm{kg}^{-1}\right)$ intraperitoneally before exposure to $100 \% \mathrm{O}_{2}$ for $24 \mathrm{hr} ; \mathrm{G}=$ dimethylthiourea $(500$ $\mathrm{mg} \cdot \mathrm{kg}^{-1}$ ) intraperitoneally before exposure to $100 \% \mathrm{O}_{2}$ for $24 \mathrm{hr}$; $\mathrm{H}=$ dimethylthiourea $\left(500 \mathrm{mg} \cdot \mathrm{kg}^{-1}\right)$ intraperitoneally before exposure to room air for $24 \mathrm{hr}$.

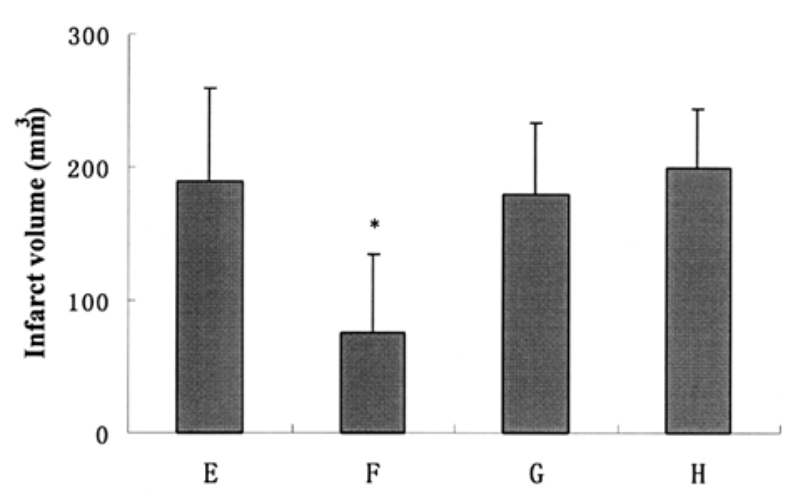

FIGURE 2 Infarct volumes at $24 \mathrm{hr}$ after reperfusion. ${ }^{*} \mathrm{P}=$ 0.001 compared with Group E. Data are presented as mean \pm SD. $\mathrm{E}=$ control group, normal saline $\left(5 \mathrm{~mL} \cdot \mathrm{kg}^{-1}\right)$ intraperitoneally before inhaling room air for $24 \mathrm{hr} ; \mathrm{F}=$ normal saline $\left(5 \mathrm{~mL} \cdot \mathrm{kg}^{-1}\right)$ intraperitoneally before exposure to $100 \% \mathrm{O}_{2}$ for $24 \mathrm{hr} ; \mathrm{G}=$ dimethylthiourea $\left(500 \mathrm{mg} \cdot \mathrm{kg}^{-1}\right)$ intraperitoneally before exposure to $100 \% \mathrm{O}_{2}$ for $24 \mathrm{hr} ; \mathrm{H}=$ dimethylthiourea $\left(500 \mathrm{mg} \cdot \mathrm{kg}^{-1}\right)$ intraperitoneally before exposure to room air for $24 \mathrm{hr}$ before focal cerebral ischemia.

volumes among the $\mathrm{B}, \mathrm{C}$ and $\mathrm{A}$ (control) Groups (Figure 1).

\section{Experiment 2}

The NDS in Group F were significantly lower than in the control group $(P=0.036)$. There was no difference in NDS among the G, H and E (control) Groups (Table III).
The infarct volume in Group F was significantly smaller than in the control group $(60 \%$ reduction, $P=$ $0.001)$. There was no significant difference in infarct volumes among the $\mathrm{G}, \mathrm{H}$ and $\mathrm{E}$ (control) Groups (Figure 2).

\section{Discussion}

This study demonstrates that pre-ischemic exposure to pure $\mathrm{O}_{2}$ for $24 \mathrm{hr}$ is able to induce tolerance against ischemic cerebral damage after transient middle cerebral artery occlusion (MCAO) in rats. Administration of a free $\mathrm{O}_{2}$ radical scavenger, DMTU, before inhaling $100 \% \mathrm{O}_{2}$ abolished the IT induced by pure $\mathrm{O}_{2}$ preconditioning.

It has been reported previously that preconditioning with repeated hyperbaric $\mathrm{O}_{2}(\mathrm{HBO})$ could induce IT in the brain, ${ }^{9-11,13}$ spinal cord ${ }^{12}$ and liver. ${ }^{18}$ Wada $e t$ al. demonstrated that pretreatment with two atmosphere absolute (ATA) HBO once every other day for three or five sessions induced IT in gerbil hippocampus. ${ }^{9,11}$ However, pretreatment with two ATA hyperbaric air once every other day for five sessions did not. ${ }^{11}$ In our previous study, we found that pretreatment with 2.5 ATA $100 \% \mathrm{O}_{2}$ one hour every day for five days could reduce infarct volume in transient MCAO rats ${ }^{10}$ and attenuate ischemic injury in spinal cord ischemia rabbits ${ }^{12}$ but that pretreatment with 2.5 ATA hyperbaric air did not induce any tolerance against spinal cord ischemia. ${ }^{12}$ The results indicated that it is hyperoxia, not hyperbaricity, that induces IT. Therefore, we hypothesized that pretreatment with $100 \% \mathrm{O}_{2}$ inhalation might induce IT. The result of experiment 1 in the current study demonstrates that pre-ischemic exposure to $100 \% \mathrm{O}_{2}$ for $24 \mathrm{hr}$ can induce tolerance against focal cerebral ischemia in rats.

Reactive $\mathrm{O}_{2}$ species (ROS) have been reported to contribute to IT in the brain ${ }^{14,19}$ and to induce IT in the heart. ${ }^{20}$ Long duration and high concentration $\mathrm{O}_{2}$ therapy produce ROS. ${ }^{21}$ Wada et al. suggested that hyperbaric $\mathrm{O}_{2}$ might promote IT by generation of $\mathrm{O}_{2}$ radicals. ${ }^{11}$ We designed experiment 2 to determine the role of ROS in the induction of IT induced by $\mathrm{O}_{2}$ pretreatment. ROS include a variety of diverse chemical species such as superoxide anions, $\mathrm{OH}$ and hydrogen peroxide. $\mathrm{OH}$ was reported to play an important role in brain IT induction. ${ }^{16}$ We used DMTU to abolish ROS. DMTU is an agent that is highly diffusible, has a long serum half-life of $43 \mathrm{hr}$, and is highly effective in scavenging $\mathrm{OH} .{ }^{22-24}$ In our experiment, rats inhaled $100 \% \mathrm{O}_{2}$ for $24 \mathrm{hr}$, which was within the halflife of DMTU. The administration of DMTU before inhalation of $\mathrm{O}_{2}$ abolished IT, suggesting that the effect of preconditioning with pure $\mathrm{O}_{2}$ is related to the 
production of OFR, especially $\mathrm{OH}$. Due to the long half-life of DMTU, which might itself result in neuroprotection during ischemia-reperfusion, Group $\mathrm{H}$ was included in this study. The results indicate that no such effect of DMTU was observed.

How $\mathrm{O}_{2}$ exposure-induced OFR induce IT is not known exactly. Various stimuli are able to induce tolerance against cerebral ischemia and it is not clear at present whether these models activate distinct pathways or if all of them share a common mechanism. Several preconditioning stimuli, including hyperbaric $\mathrm{O}_{2}$ and hypoxia can induce the production of OFR, ${ }^{11,16}$ which were suggested to present a common signal in IT induction. ${ }^{14,15}$ Das et al. ${ }^{15}$ demonstrated that ROS can act as a second messenger during ischemic preconditioning of the heart. ROS generated during preconditioning triggers a tyrosine kinasedependent signal transduction and results in enhanced phosphorylation and activation of microtubule-associated protein kinase cascade leading to the activation of nuclear factor kappa B (NF $\kappa \mathrm{B})$. Activation of NF $\kappa \mathrm{B}$ is likely to be involved in the induction of gene expression associated with the ischemic adaptation. Further studies are needed to investigate the exact mechanism of tolerance induced by pure $\mathrm{O}_{2}$ inhalation.

The ischemic model used in our experiments is widely accepted. Many other ischemic models are used in different experiments. Unfortunately, the transfer of the exciting therapeutic results obtained in animals to human trials has been dismal failure. Drummond $e t$ $a l .^{25}$ suggested that a prime reason for the failure of human clinical trials might reside, not in the design of these trials, but in the design of the preclinical studies that generated the optimism for the numerous agents that have gone on to full clinical trials. In our study we evaluated neurological and histological results at $24 \mathrm{hr}$ after reperfusion. Therefore, substantially more information on $\mathrm{O}_{2}$ inhalation-induced IT must be obtained before it can be advocated in humans.

In our experiments, we monitored the rectal temperature during the operation but did not monitor brain temperature. Brain temperature might decrease during cerebral ischemia and anesthesia ${ }^{26}$ but the rectal temperature was controlled at the same level in all animals, which reduced bias in experimental ischemic injury among groups.

We only investigated the neuroprotective effects at $24 \mathrm{hr}$ after pretreatment with $100 \% \mathrm{O}_{2}$. Further studies are needed to clarify the shortest time of $\mathrm{O}_{2}$ inhalation capable of inducing IT, the time window of IT after $\mathrm{O}_{2}$ pretreatment, and the possible side effects produced by inhalation of high concentrations of $\mathrm{O}_{2}$ before considering extrapolating this technique to humans.
In conclusion, the present study demonstrated, that in rats, exposure to $100 \% \mathrm{O}_{2}$ for $24 \mathrm{hr}$ can induce IT. IT was related to the production of OFR.

\section{References}

1 Dawson TD. Preconditioning-mediated neutoprotection through erythropoietin? Lancet 2002; 359: 96-7.

2 Obtsuki T, Ruetzler CA, Tasaki K, Hallenbeck JM. Interleukin-1 mediates induction of tolerance to global ischemia in gerbil hippocampal CAl neurons. J Cereb Blood Flow Metab 1996; 16: 1137-42.

3 Tasaki K, Ruetzler CA, Obstuki T, Martin D, Nawashiro H, Hallenbeck JM. Lipopolysaccharide pretreatment induces resistance against subsequent focal cerebral ischemic damage in spontaneously hypertensive rats. Brain Res 1997; 748: 267-70.

4 Nawashiro H, Tasaki K, Ruetzler CA, Hallenbeck JM. TNF-alpha pretreatment induces protective effects against forcal cerebral ischemia in mice. J Cereb Blood Flow Metab 1997; 17: 483-90.

5 Yanamoto $H$, Hashimoto $N$, Nagato I, Kikuchi $H$. Infarct tolerance against temporary focal ischemia following spreading depression in rat brain. Brain Res 1998; 784: 239-49.

6 Bernaudin M, Marti HH, Roussel S, et al. A potential role for erythropoietin in focal permanent cerebral ischemia in mice. J Cereb Blood Flow Metab 1999; 19: 643-51.

7 Wiegand F, Liao W, Busch C, et al. Respiratory chain inhibition induces tolerance to focal cerebral ischemia. J Cereb Blood Flow Metab 1999; 19: 1229-37.

8 Weih M, Bergk A, Isaev NK, et al. Induction of ischemic tolerance in rat cortical neurons by 3 -nitropropionic acid: chemical preconditioning. Neurosci Lett 1999; 272: 207-10.

9 Wada K, Ito M, Miyazawa T, et al. Repeated hyperbaric oxygen induces ischemic tolerance in gerbil hippocampus. Brain Res 1996; 740: 15-20.

10 Xiong L, Zhu Z, Dong H, Hu W, Hou L, Chen S. Hyperbaric oxygen preconditioning induces neuroprotection against ischemia in transient not permanent middle cerebral artery occlusion rat model. Chin Med J 2000; 113: 836-9.

11 Wada K, Miyazama T, Nomura N, Tsuzuki N, Nawashiro H, Shima K. Preferential conditions for and possible mechanisms of induction of ischemic tolerance by repeated hyperbaric oxygenation in gerbil hippocampus. Neurosurgery 2001; 49: 160-7.

12 Dong H, Xiong L, Zhu Z, Chen S, Hou L, Sakabe T. Preconditioning with hyperbaric oxygen and hyperoxia induces tolerance against spinal cord ischemia in rabbits. Anesthesiology 2002; 96: 907-12.

13 Prass K, Wiegand F, Schumann P, et al. Hyperbaric 
oxygenation induced tolerance against focal cerebral ischemia in mice is strain dependent. Brain Res 2000; 871: 146-50.

14 Ravati A, Ablemeyer B, Becker A, Klumpp S, Krieglstein $J$. Preconditioning-induced neuroprotection is mediated by reactive oxygen species and activation of the transcription factor nuclear factor- $\kappa \mathrm{B}$. J Neurochem 2001; 78: 909-19.

15 Das DK, Maulik N, Sato M, Ray PS. Reactive oxygen species function as second messenger during ischemic preconditioning of heart. Mol Cell Biochem 1999; 196: 59-67.

16 Rauca C, Zerbe R, Jantze H, Krug M. The important of free hydroxyl radicals to hypoxia preconditioning. Brain Res 2000; 868: 147-9.

17 Longa EZ, Weinstein PR, Carlson S, Cummins R. Reversible middle cerebral artery occlusion without craniectomy in rats. Stroke 1989; 20: 84-91.

18 Chen MF, Chen HM, Ueng SW, Shyr MH. Hyperbaric oxygen pretreatment attenuates hepatic reperfusion injury. Liver 1998; 18: 110-6.

19 Blondeau N, Widmann C, Lazdunski M, Heurteaux C. Activation of the nuclear factor- $\kappa \mathrm{B}$ is a key event in brain tolerance. J Neurosci 2001; 21: 4668-77.

20 Forbes RA, Steenbergen C, Murphy E. Diazoxideinduced cardioprotection requires signaling through a redox-sensitive mechanism. Circ Res 2001; 88: 802-9.

21 Mickel HS, Vaishnav YN, Kempski O, von Lubitz D, Weiss JF, Feuerstein G. Breathing 100\% oxygen after global brain ischemia in Mongolian gerbils results in increased lipid peroxidation and increased mortality. Stroke 1987; 18: 426-30.

22 Fox RB. Prevention of granulocyte-mediated oxidant lung injury in rats by a hydroxyl radical scavenger, dimethylthiourea. J Clin Invest 1984; 74: 1456-64.

23 Kinugawa S, Tsutsui H, Hayashidani S, et al. Treatment with dimethylthiourea prevents left ventricular remodeling and failure after experimental myocardial infarction in mice. Role of oxidative stress. Circ Res 2000; 87: 392-8.

24 Pattanaik $U$, Prasad K. Reactive oxygen species and endotoxic shock: effect of dimethylthiourea. J Cardiovasc Pharmacol Ther 2001; 6: 273-85.

25 Drummond JC, Piyash PM, Kimbro JR. Neuroprotection failure in stroke (Letter). Lancet 2000; 356: 1032-3.

26 Drummond JC. Brain protection during anesthesia. A reader's guide. Anesthesiology 1993; 79: 877-80. 